\title{
The Necessity of Increasing Livability for George Town World Heritage Site: An Analytical Review
}

\author{
Mohammad Javad Maghsoodi Tilaki ${ }^{1}$, Aldrin Abdullah ${ }^{2}$, Azizi Bahauddin ${ }^{2} \&$ Massoomeh Hedayati Marzbali ${ }^{2}$ \\ ${ }^{1}$ Department of Urban Planning, Payame Noor University, Iran \\ ${ }^{2}$ School of Housing, Building \& Planning, Universiti Sains Malaysia, Penang, Malaysia \\ Correspondence: Assistant professor, Department of Urban Planning, Payame Noor University, Po Box \\ 19395-3697 Tehran, Iran. Tel: 60-174-058-454. E-mail: maghsoodi@usm.my
}

\author{
Received: October 24, $2013 \quad$ Accepted: December 27, $2013 \quad$ Online Published: January 9, 2014 \\ doi:10.5539/mas.v8n1p123 URL: http://dx.doi.org/10.5539/mas.v8n1p123
}

\begin{abstract}
The George Town heritage area in Malaysia was listed as a world heritage site by UNESCO in 2008 . Such a nomination brings international accountability with extensive constructive influence on the local and regional development processes as the tourism industry is the second largest source of foreign exchange revenue in Malaysia. Drawing on the socio-economic effects of livability in environmental development on the George Town heritage area, the research goal is to advance the livability in the George Town heritage area in two stages. Initially, the research focuses on the livability concepts and principals as important elements to recognize the significance of livability. Secondly, the study attempts to identify the impact of livability in the George Town heritage area based on evidence drawn from other contexts, such as Central Europe. Consequently, the research addresses the role of livability to improve the built environment, safety, public participation, cultural identity and tourist satisfaction in different communities, especially in the heritage area. By considering the role of the tourism industry in Malaysia's economic growth, the research concludes that livability is a very important component that ensures the improvement of the environment, including the facilities and infrastructure, and encourages people's contribution to develop George Town heritage area to be a better tourist attraction. However, conversely, increasing the quality of the habitation in the Malaysian heritage area has still not been properly addressed.
\end{abstract}

Keywords: livability, heritage area, George Town, tourist satisfaction, public participation

\section{Introduction}

Over the last few decades, the rapid urbanization has transformed the world's development patterns through a combination of economic growth and social change. Accompanying this rapid growth of the urban population are an increase in the levels of poverty, inequality and social distance, unemployment, and the rate of crime. Moreover, inner-cities and the cores of cities have been widely influenced by rapid urbanization, such as changes in people's lifestyle. These areas lose their social value and public participation when people withdraw from the community life (Skogan, 1986) and consequently, reduce their social communication, walking and cycling time in public spaces and city centers in response to their safety concerns and environmental challenges, such as noise pollution, and traffic junctions.

The urban core, beyond simply acting as a place for people to live, is recognized as a valuable place in cities where people walk, inform, meet, have fun, shop, and, generally, get involved with different social and entertaining activities. As the activities are some of the enjoyable aspects of urban living, these activities in the historical areas of cities influence the sense of the quality of life among many urban visitors and residents. Usually, the historical areas in cities are the initial core or heart of the cities, through which several physical components illustrate the historical background of cities. Additionally, different research describes a city's core as reflecting the social context of the city due to the diversity of people in different positions, such as retailing, housing, entertainment; and a mix of civic, administrative and professional services (Balsas, 2004; McCann, 2003). This study's focus is on the livability, as it addresses people's sense of well-being, and the support of decision makers in an area. Furthermore, although new urbanists have made the concept of a safe city, livability has also the ability to reduce crime by enhancing opportunities for interaction among people, increasing the sense of community, and neighborhood watch in cities (Hedayati et al., 2012). 
The goal of this paper is to review the impact of livability on the George Town heritage area in Penang state, which is located in the North West of Malaysia. This heritage area as a world heritage site is located at the city's core, which is visited by a large number of tourists and residents every year. Hence, the livability of the site is an important matter for relevant stakeholders including the authorities, retailers, residents and tourists. The significance of the research is twofold. Firstly, cultural/heritage tourists constitute the fastest growing segment of the tourism industry (Joshi, 2012) and the tourism industry is the second largest source of foreign exchange revenue in Malaysia (Mazumder et al., 2009). Secondly, whilst Malaysia, as a multi-cultural country, is trying to introduce its cultural identity to the world, this nomination brings international accountability to the Malaysian government.

\section{Materials and Methods}

The review is based on literature reported in the root disciplines of social, economic, and physical aspects of environment in livability, quality of life and sustainable development. A set of keyword combinations -cultural identity, public involvement, participatory governance, tourism satisfaction, and environmental livability - were employed to conduct the literature search. This research applied online searching approach to navigate available sources among several databases such as Science Direct, Springer, Taylor and Francis and Scopus. Articles were considered which have been published between 1992 and 2013, especially for the empirical studies, both quantitative and qualitative but include theoretical aspects. Thus, a large body of literature was created to illustrate an in-depth understanding of the theoretical side of livability concept and its role in enhancing function at Penang heritage area and the tourism industry. A greater emphasis was placed on literature that addresses the characterization of public participation in the form of attitudinal responses towards development and conservation strategies.

This paper first provides a comprehensive review of the body of literature concerning the livability concept and principals, and then proceeds by outlining the impact of livability on the different effective elements of the community. These sections prepare an understanding for identifying the effective ingredients concerning the increasing quality of the habitat, and transforming the perceptions of visitors and tourists. The findings are based on an in-depth analysis of relevant research, journal papers and policy documents. It is expected that the research findings will assist authorities to improve tourist satisfaction in the George Town heritage area by increasing livability.

\subsection{George Town Heritage Area}

As Malaysia is one of the countries in Southeast Asia that is experiencing rapid economic development, the expanding urbanization is one of the significant phenomena facing the nation. The economic growth has occurred through the rapid growth of different sectors of which the tourism industry is currently the second largest foreign exchange earner, after manufacturing. Furthermore, Malaysia is endowed with an abundance of attractions for tourists including natural and heritage resources that are particularly suitable for sustainable tourism (Mazumder et al., 2009). This specific situation provides an exclusive foundation to expand the Malaysian tourism industry as well as introduce Malaysian culture. The review of census data indicates that inbound tourism has grown extensively over the last three decades. This puts into perspective the importance of improving the tourist attractions.

One of the major parts of Malaysia's tourist attractions includes its cultural institutions, which are located in heritage areas. As surrogate representations, they are emphasized as representing Malaysia's culture heritage. Hence, the improvement and enhancement of heritage areas should be considered as a fundamental function for the development of Malaysia's tourism industry (Manaf \& Ismail, 2010). With regard to the exclusive character including a combination of religious pluralism, historic townscapes, and living heritage, this study selected George Town, the capital of Penang state, as the case study to examine the impact of livability in this area (Figure 1). The review of related reports indicates that George Town has been designated as a World Heritage Site due to some Outstanding Universal Values (OUV), which are classified into three major parts:

- Multicultural trading port;

- Multicultural community, which refers to the living testimony of the multicultural heritage and tradition of Asia, and European colonial influences; and

- A unique architecture, culture and townscape multi-trading Port (Shop-houses and Town-houses (UNESCO, 2008). 


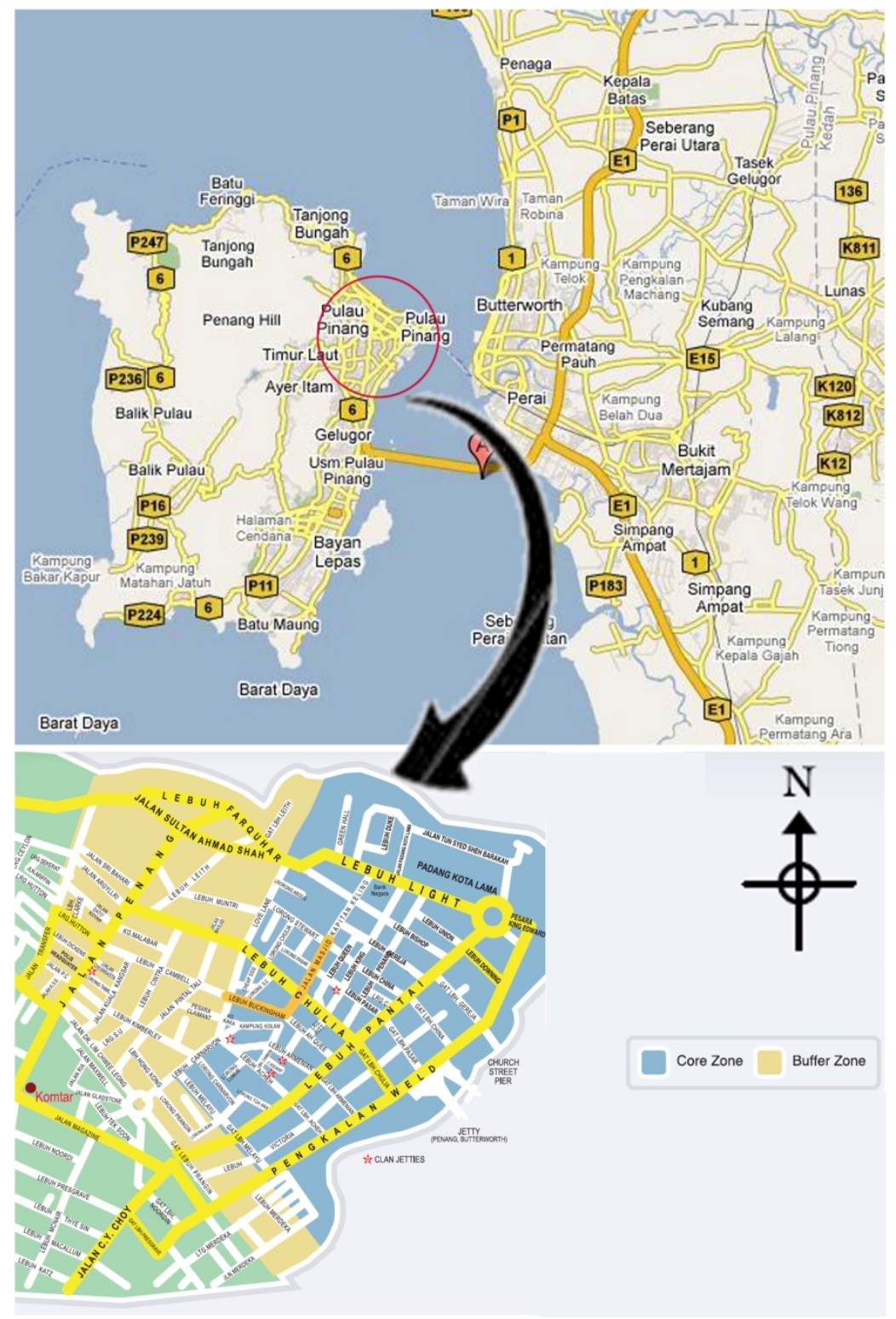

Figure 1. Site plan for George Town heritage area

Consequently, the nomination of George Town as a 'World Heritage Site' has provided a great opportunity to develop cultural tourism. The World Heritage Site status has expanded the potential to boost the market and investment in tourism related businesses and real estate as well as other fields that were influenced by the jump in the market in George Town after its nomination. Hence, the improvement of George Town heritage area is necessary to maximize the opportunity for more tourist arrivals. As there is a significant correlation among tourism services, tourist satisfaction and livability, increasing livability can assist the improvement of George Town heritage area. Furthermore, George Town is located in the central part of Penang Island where there is an overlap among the commercial, administrative and heritage buildings, as well as religious activities. This position of George Town heritage area is a boost because city centers reflect the social context of cities due to the diversity of people in different positions, such as retailing, housing, entertainment, and a mix of civic, administrative and professional services (Balsas, 2004).

\section{Livability Concepts and Principals}

Nowadays, the concept of livability has been focused on by a large body of studies that have revealed the significance of livability for communities including the requirements for more consideration by planners, designers and policy makers throughout the developed countries (Schomberg et al., 2011). Livability is 
recognized as a holistic concept (Andrews, 2001; Saitluanga, 2013) and is close to the human concept (Wyatt, 2009). It has been described by different meanings depending on the place, time, and focus of the study (Pacione, 2003 ) with no universally agreed interpretation (NRC, 2002). Throughout the review of the literature, livability has been considered as people's needs for public amenities (Anderson et al., 1997; Besser et al., 2012; Frey et al., 2007) and is recognized as a major element to create social welfare (Anderson et al., 1997; Smith, 1973). Moreover, there is a considerable conceptual overlap between livability and sustainability (Allen, 2010; Sanford, 2011), and the quality of life as well (Hovey, 2008; McCann, 2007; Saitluanga, 2013; Schomberg et al., 2011), albeit their meanings are dissimilar, and their effects and views are on different scales (Hovey, 2008). In summary, livability is defined as a collection of characteristics that explain the attractive elements of a place for people to live and rest. Regarding the concept of livability, the environment is the basic aspect of the community to increase livability as it assembles other aspects of the community and affects people's behavior (Linden, 1996).

From another angle, urban livability is a complicated idea and directs attention to the different attributes that contribute to an urban community's overall quality of life (Loewus, 2008). Urban livability attempts to motivate urban areas towards an ideal level (McCann, 2008) and is applied in three aspects of the community: environmental quality, neighborhood amenity and individual well-being (S. Lennard \& H. Lennard, 1995). In addition, urban livability considers reaching the appropriate motivation level in cities through focusing on economic and social concerns of urban life as well as environmental aspects including urban design and public space usage.

The urban livability concepts have been debated by researchers and scholars and they have extracted different characters to create a livable city based on their perspectives. Kevin Lynch (1981, p. 1) introduced five elements - vitality, sense, fit, access and control - for making good cities; however, after two decades, Balsas (2004) endorsed Lynch's belief and added the element of viability. Douglass (2000) argued that the realization of a livable city could be achieved through increasing the quality of life. In this light, he believes that urban livability is founded on four cornerstones: (1) to enjoy widening life chances through direct investment in talent and well-being, (2) access to meaningful work and livelihood opportunities, (3) having a safe and clean environment, and (4) establishing good governance. Moreover, in another body of literature, the livability principles have been concluded and summated into six major domains (Partnership for Sustainable Communities, 2011):

(1) Provide more transportation choices to decrease household transportation costs, reduce dependence on oil, improve air quality and promote public health.

(2) Expand location- and energy-efficient housing choices for people of all ages, incomes, races and ethnicities to increase mobility and lower the combined cost of housing and transportation.

(3) Improve the economic competitiveness of neighborhoods by giving people reliable access to employment centers, educational opportunities, services and other basic needs.

(4) Target federal funding for existing communities - through transit-oriented and land recycling - to revitalize communities, reduce public work costs, and safeguard rural landscapes.

(5) Align federal policies and funding to remove barriers to collaboration, leverage funding and increase the effectiveness of programs to plan for future growth.

(6) Enhance the unique characteristics of all communities by investing in healthy, safe and walkable neighborhoods, whether rural, urban or suburban.

Generally, the body of literature indicated that the livability principals seek to describe different strategies in several domains including social, environmental, and economic to achieve sustainability goals in communities.

\section{The Impact of Community Issues on Livability}

As mentioned in past, the research objective is to show the necessity of increasing livability on the George Town heritage area in Penang state. Although, the concept of livability is broad to debate in different aspects of knowledge but some the prominent concerns such as built environment, safety, and public participation have extremely influenced on the heritage area livability and urban tourist in Asia pacific countries such as Malaysia (Anuar et al., 2010; Douglass, 2000; Yung \& Chan, 2011). According to the review of the literature, the study emphasized on three aforementioned elements to indicate the effect of these three elements on livability and how these components can growth tourist industry in George Town heritage area. Finally, current study verifies necessity of heritage areas to increasing livability to play their roles in social, cultural, and economic aspects of comunities. 


\subsection{Built Environment and Livability}

With respect to the new urban planning concepts, a large body of literature concerning the built environment has focused on the relationship among people's behavior and their perceptions with urban land use distribution, public space, and urban spatial patterns (Badoe \& Miller, 2000; Barton, 2009; Hostetler et al., 2003; Joh et al., 2012; Lee \& Moudon, 2006; Wilhelmi \& Hayden, 2010). Studies have revealed that there are considerable connections between people's behavior and the built environment as well as urban land use (Handy et al., 2002; Joh et al., 2012; Lee et al., 2006). The built environment is formed based on the people's decisions whilst the people's behaviors are influenced by the built environment, especially in cities. The results of several studies indicated that the distribution of landmark land use (public space, shopping complex, traffic junction, square) and urban connectivity through a transportation network are effective elements for shaping people's lifestyle and their perceptions (Boarnet et al., 2011; Joh et al., 2012; Krizek, 2003). Some research also presented that the distribution of land use and the connectivity influences people's behavior such as walking trips (Ewing \& Cervero, 2010; Frank \& Pivo, 1994). These studies concluded that people's activities in public spaces largely depend on the connectivity and distribution of land use in cities, inasmuch as these elements have an effect on people's safety and security. On the other hand, there is a strong link among walking, people's activity in public spaces, and health (Joh et al., 2012; McMillan, 2007; Zhu \& Lee, 2009) whilst health is a key indicator in the urban livability. Therefore, the built environment plays a major role in people's activities and increases the livability in communities, especially in cities.

\subsection{Safety and Livability}

Safety as a basic human right has been emphasized by developed and developing countries, and the safety and perception of safety are involved in assessing the overall health in communities. Usually, safety covers several aspects of people's lives and activities in communities, such as home, public areas, shopping complexes, and private and public organizations. Hence, the needs for a safe physical environment have been highlighted more in urban areas after the cities grow, with the concomitant increase in urban population, and distance social levels.

Over the last five decades, the link between the built environment and crime has been primarily emphasized by a number of researchers and scholars, such as Jane Jacobs' (1961) "eyes on the street" theory and Oscar Newman's (1972) "defensible space" concept. Both Jacobs and Newman focused on the role of the built environment on crime and social activates, and consequently the impact of social activities on safety of the environment. The results of their studies emphasize the importance of the environmental aspect including land use and street pattern in respect of crime and safety. They believed that the establishment and development of natural surveillance ensures safe communities and increases the satisfaction of residents (Hedayati et al., 2012). Hedayati and colleagues (2012) concluded that the characteristics of the built environment play a major role in promoting and improving safety in urban settings with reference to their assessment on crime prevention through environmental design. From another angle, a body of literature argued that there is a high crime rate and even fear of crime in specific nodes at public spaces, such as bus stations at the cities known as crime hotspots (Joh et al., 2012; Loukaitou-Sideris, 1999; Nasar \& Fisher, 1993). In accordance with this debate, the results of a study in South East Asia revealed that there is a positive relationship between crime rate and fear of crime in residential areas (Hedayati, 2012).

Furthermore, the impact of the fear of crime and people's activity in public areas and streets has been examined in several studies. The evidence showed that there is a positive association between the fear of crime and people's activity (McDonald, 2008). Thus, neighborhood safety can be improved by promoting more people's activity in public areas (Abdullah et al., 2013; Joh et al., 2012). However, as the elements mentioned are a major part of people's lives, any changes thereto will modify their level of living satisfaction and urban livability for which health and safety are two indicators to measure livability.

\subsection{Public Participation and Livability}

Over the last few decades, public participation has been a common recommendation of several of the environmental planning approaches to improve the quality of the environment. Basically, public participation is recognized as a set of functions by people to determine and make decisions in different social fields. Gerson (1993) explained that public participation is a process through which people present their opinions about policy formulation, planning alternatives, investment options, and management. The comprehensive planning methods applied in different countries in the 1970s emphasized linear and top-down approaches, and, hence, people and the private sector were not involved in the decision-making and decision-taking processes. However, disempowerment of people and the local communities in decision-making has been noted by several studies (such as Harris, 1994). After several decades, other planning concepts introduced different approaches for the 
preparation and implementation of plans or policies that were established through the idea of participation and down-top method. Thus, the comprehensive planning approach, as one of the effective planning approaches in the environmental scope, has been declining in most countries since the 1980s when the strategic planning approach came to the fore in developed countries, since when it has been widely employed by authorities in environmental planning (UN-Habitat, 2007).

From another angle, public participation is fundamental to the growth of the social aspect in different communities. A body of literature promotes the public participation idea for making a better environment based on four major reasons: (1) community involvement makes the goals of the plans or policies achievable, (2) the results of the plans or policies are accepted by the community stakeholders, (3) people's participation provides support to the relevant authorities to reduce the cost of implementing the plan or policies as they play their part with more willingness, and (4) public participation increases social cohesion in the community (Hedayati et al., 2012; Rydin \& Pennington, 2010).

Furthermore, people's involvement and their participation have been recognized as two effective elements in the economic process inasmuch as public participation creates opportunities for bringing different expertise and comprehensive information (Wateco, 2002). There have been different results from enabling public participation in the decision process in several aspects of communities and it is considered as an indicator to evaluate the process of community development, quality of life, and livability. Taken as a whole, public participation has considerable ability to improve social cohesion, economic growth, enabling accessibility to the decision processes, and people's willingness. Thus, public participation has been accepted as one of the instruments and strategies to increase livability in the communities. Furthermore, improvement of public participation can increase livability through reducing crime in the communities as it creates public surveillance and neighborhood watch.

\subsection{Tourist Satisfaction and Livability}

As mentioned above, the tourism industry has a key role in Malaysia's economic structure. Based on the available census, Malaysia received 25.03 million inbound international tourists and a revenue of approximately 60.6 billion ringgit (US\$20 billion), of which 3 million tourists visited the state of Penang in 2012 (Ministry of tourism Malaysia, 2011). The number of and the amount of revenue from the tourists reveal how vital the role of this industry is in respect of Malaysia's development. While the tourism industry relies on the expansion of adequate and modern infrastructure and facilities to establish a world-class tourist attraction (Jawong, 2013), the idea is only achievable when tourists and residents have high satisfaction with their quality of life. Muller (1996) explained that improving the livability also modifies the level of tourist satisfaction. Kruger and Petzer (2008) argued that livability can influence the level of tourist satisfaction based on four different components: satisfaction with travel/tourism services, satisfaction with travel/tourism experiences, satisfaction with leisure life, and satisfaction with life in general. Referring to the aforementioned components, tourism service is a unique component that is objective and tangible, while the other components are subjective such as fear of well-being. Consequently, the tourism authorities must focus on improvement to the tourism service and infrastructure when attempting to increase tourist numbers. However, there is a challenge to establish or upgrade tourism services in developing and undeveloped countries, which relates to the financial limitations.

\subsection{Heritage Area and Livability}

Basically, a heritage area is recognized as a quarter including historical elements that have been inherited from previous decades or centuries to the current time (Imon et al., 2007). Nuryanti (1996) described heritage as a component of the cultural tradition in each settlement and community. Moreover, heritage has been recognized as a significant element for social and community well-being (Tweed \& Sutherland, 2007). From another angle, the built heritage as a part of cultural heritage presents the chronological fundamentals of a community, therefore, architectural concepts and historical worth can be seen in built heritage. Hence, heritage areas including built heritage are studied and esteemed by people who like to know about past times, such as tourists and researchers.

Consequently, heritage areas have been broadly considered as being able to embrace people with different perspectives. Tweed and Sutherland (2007) believe that heritage mainly refers to increasing people's sense of belonging and their enthusiasm for the subject of cultural identity. As identity and sense of belonging are recognized as two effective elements in community livability, heritage areas can influence the livability. Therefore, there is a positive correlation between heritage areas and livability inasmuch as heritage areas increase livability in communities, such as cities. Therefore, heritage areas can play a role in increasing the livability when the area strengthens the sense of belonging. These areas also can design culture identity through employing appreciate conservation approach to achieve strong sense and imaging. 
In Malaysia, heritage areas make a considerable contribution to the national economic growth through heritage tourism. However, UNESCO has emphasized that several elements threaten the heritage in Asia (UNESCO, 2009). Heritage tourism also promotes Malaysia's culture and creates an opportunity to appreciate, maintain and conserve the heritage areas, which are the focus of tourists. This chance is highlighted in both George Town and Melaka as two world heritage areas in Malaysia. The prospect can encourage planners and authorities to boost the sense of belonging and cultural identity, which improves livability and increases tourist arrivals in Malaysia's heritage area. In addition, while heritage areas in Malaysia have a major role and ability to participate in the progress of national development, they need to be reviewed and the policy and approach to conserve and boost cultural identity evaluated.

\section{Conclusions}

The results achieved from this study present a set of remarkable perspectives for researchers and relevant authorities that contribute to the objectives in heritage areas, the tourism industry and social concerns. According to Palmer (2005), there is a knowledge gap concerning the built heritage and collective belonging, hence, the current study has attempted to concentrate on increasing livability in the George Town heritage area and addressing the impact of livability on the social cohesion, economic growth, and cultural identity. As foreseen, the Malaysian heritage areas are appropriate elements for transforming the quality of the environments at their periphery, which has several positive effects on the Malaysian built environment. The effects include wide domains from economic growth to debates about cultural identity. Indeed, the George Town heritage area, as a world heritage site, has been focused on by UNESCO due to its outstanding universal value, which can be considered as an engine of growth for Malaysia. Hence, its contribution influences different aspects of existence on Penang Island including social, economic and physical. Due to the unique role, this research has reviewed the concept of livability and its relationship with certain social concerns, such as crime, public participation, and the built environment. From the review of the literature, a series of barriers, such as traffic congestion, crime, and social fragmentation, has prevented the increasing livability in communities. As a consequence, the current study concludes that the livability can be increased in the George Town heritage area through some effective actions that promote safety, compatible land use distribution, friendly environmental design, and boost public participation. The article explained that the increasing livability ensures growth, development at Penang Island through improving different aspects of life and increasing tourist arrivals as the major key for development in Malaysia. The increase in livability is influenced by a number of factors in the community, such as decision-making power, economic conditions, and social cohesion. Generally, the potential of the George Town heritage area provides a chance to develop the Penang tourism industry as a hotspot among the other tourist attractions in Malaysia whilst relying on increasing the livability.

To conclude, it seems that Malaysia is in the distinguished position of possessing a unique, multi-cultural community, which, although prominent, has been neglected. However, it appears that the livability in the heritage area is key to the future development of Malaysia. Malaysia should attempt to further embrace tourists in a way that focuses on a livable environment. Thus, the concept of livability must not be neglected as a means of fostering heritage attractions and the level of social satisfaction, but, instead, should be used as an opportunity to develop the Malaysian community towards achieving the One Malaysia programme.

\section{Acknowledgements}

The authors would like to thank the Universiti Sains Malaysia for providing financial support for this study.

\section{References}

Abdullah, A., Hedayati Marzbali, M. H., Woolley, H., Bahauddin, A., \& Maliki, N. Z. (2013). Testing for Individual Factors for the Fear of Crime Using a Multiple Indicator-Multiple Cause Model. European Journal on Criminal Policy and Research, 1-22. http://dx.doi.org/10.1007/s10610-013-9208-4

Allen, T. F. (2010). Making livable sustainable systems unremarkable. Systems Research and Behavioral Science, 27(5), 469-479. http://dx.doi.org/10.1002/sres.1059

Anderson, E., Simpson, R., Kitching, R., Simpson, R., Conacher, A., Smith, D. I., \& Laird, P. (1997). State of the Environment 1996. Australasian Journal of Environmental Management, 4(2), 157-184. http://dx.doi.org/10.1080/14486563.1997.10648379

Andrews, C. J. (2001). Analyzing quality-of-place. Environment and Planning B, 28(2), 201-218. http://dx.doi.org/10.1068/b2714 
Anuar, A. N. A., Bookhari, S. N., \& Aziz, N. A. (2012). The effectiveness of Safe City Programme as safety basic in tourism industry: Case Study in Putrajaya. Procedia-Social and Behavioral Sciences, 42, 477-485. http://dx.doi.org/10.1016/j.sbspro.2012.04.213

Badoe, D. A., \& Miller, E. J. (2000). Transportation-land-use interaction: empirical findings in North America, and their implications for modeling. Transportation Research Part D: Transport and Environment, 5(4), 235-263. http://dx.doi.org/10.1016/S1361-9209(99)00036-X

Balsas, C. J. (2004). Measuring the livability of an urban centre: an exploratory study of key performance indicators. Planning, Practice \& Research, 19(1), 101-110. http://dx.doi.org/10.1080/0269745042000246603

Barton, H. (2009). Land use planning and health and well-being. Land Use Policy, 26, S115-S123. http://dx.doi.org/10.1016/j.landusepol.2009.09.008

Berke, P. R., \& Conroy, M. M. (2000). Are we planning for sustainable development? An evaluation of 30 comprehensive plans. Journal of the American Planning Association, 66(1), 21-33. http://dx.doi.org/10.1080/01944360008976081

Besser, T. L., Miller, N. J., \& Malik, R. (2012). Community Amenity Measurement for the Great Fly-Over Zones. Social indicators research, 106(2), 393-405. http://dx.doi.org/10.1007/s11205-011-9813-x

Boarnet, M. G., Joh, K., Siembab, W., Fulton, W., \& Nguyen, M. T. (2011). Retrofitting the suburbs to increase walking: Evidence from a land-use-travel study. Urban studies, 48(1), 129-159. http://dx.doi.org/10.1177/0042098010364859

Cohen, B. (2006). Urbanization in developing countries: Current trends, future projections, and key challenges for sustainability. Technology in society, 28(1), 63-80. http://dx.doi.org/10.1016/j.techsoc.2005.10.005

Dato Sri Michael Manyin Jawong. (2013). Tourism planning vital part of city's devt plan. Retrieved September 9, 2013, from http://www.theborneopost.com/2013/07/04/tourism-planning-vital-part-of-citys-devt-plan/

Dekker, K., \& Bolt, G. (2005). Social cohesion in post-war estates in the Netherlands: Differences between socioeconomic and ethnic groups. Urban Studies, 42(13), 2447-2470. http://dx.doi.org/10.1080/00420980500380360

Douglass, M. (2000). Globalization and the Pacific Asia Crisis-Toward Economic Resilience through Livable Cities. Asian Geographer, 19(1-2), 119-137. http://dx.doi.org/10.1080/10225706.2000.9684066

Elander, I. (2002). Partnerships and urban governance. International social science journal, 54(172), 191-204. http://dx.doi.org/10.1111/1468-2451.00371

Ewing, R., \& Cervero, R. (2010). Travel and the built environment: A meta-analysis. Journal of the American Planning Association, 76(3), 265-294. http://dx.doi.org/10.1080/01944361003766766

Frank, L. D., \& Pivo, G. (1994). Impacts of mixed use and density on utilization of three modes of travel: single-occupant vehicle, transit, and walking. Transportation research record, 44-44.

Frey, M. K., Ober, V., Kulik, J., \& Shoemaker, L. (2008, November). Using Rainwater to Grow Livable Communities: A New Tool to Promote Multi-Benefit BMPs. In Low Impact Development for Urban Ecosystem and Habitat Protection (pp. 1-10). ASCE.

Gerson, P. R. (1993). Popular participation in economic theory and practice. Human Resources Development and Operations Policy, World Bank.

Harris, G. (1994). The Adirondack Mountains: Wilderness preservation or bioregional vision? Trumpeter, 11(3), 117-120.

Handy, S. L., Boarnet, M. G., Ewing, R., \& Killingsworth, R. E. (2002). How the built environment affects physical activity: views from urban planning. American journal of preventive medicine, 23(2), 64-73. http://dx.doi.org/10.1016/S0749-3797(02)00475-0

Hedayati Marzbali, M., Abdullah, A., Razak, N. A., \& Maghsoodi Tilaki, M. J. (2012). The influence of crime prevention through environmental design on victimisation and fear of crime. Journal of environmental psychology, 32(2), 79-88. http://dx.doi.org/10.1016/j.jenvp.2011.12.005

Hostetler, M., \& Knowles-Yanez, K. (2003). Land use, scale, and bird distributions in the Phoenix metropolitan area. Landscape and Urban Planning, 62(2), 55-68. http://dx.doi.org/10.1016/S0169-2046(02)00096-8 
Hovey, B. (2008). In Search of Urban Vitability. Journal of Urban History, 34(3), 552-561. http://dx.doi.org/10.1177/0096144207311196

Hueting, R., \& Reijnders, L. (1998). Sustainability is an objective concept. Ecological Economics, 27(2), 139-148.

Imon, S. S., Di Stefano, L. D., \& Lee, H. Y. (2005). The Meaning of Integrated Conservation in a Historic Urban Area: A Case Study from Old Dhaka, Bangladesh. Urban Revitalization and Social Sustainability, 7-12.

Jacobs, J. (1961). The death and life of great American cities. Random House Digital, Inc.

Jennings, P. D., \& Zandbergen, P. A. (1995). Ecologically sustainable organizations: an institutional approach. Academy of Management Review, 20(4), 1015-1052.

Joh, K., Nguyen, M. T., \& Boarnet, M. G. (2012). Can built and social environmental factors encourage walking among individuals with negative walking attitudes?. Journal of Planning Education and Research, 32(2), 219-236. http://dx.doi.org/10.1177/0739456X11427914

Joshi, P. V. (2012). Planning Cultural-Heritage Tourism for Sustainable Development.

Krizek, K. J. (2003). Residential relocation and changes in urban travel: does neighborhood-scale urban form matter? Journal of the American Planning Association, 69(3), 265-281. http://dx.doi.org/10.1080/01944360308978019

Kruger, S., \& Petzer, D. (2008). Measuring tourists' satisfaction with quality of life issues at an arts festival. Acta Commercii, 8(1), 113-127.

Lee, C., \& Moudon, A. V. (2006). The 3Ds+ R: Quantifying land use and urban form correlates of walking. Transportation Research Part D: Transport and Environment, 11(3), 204-215. http://dx.doi.org/10.1016/j.trd.2006.02.003

Lennard, S., \& Lennard, H. (1995). Livable cities observed. Southampton: Gondolier Press.

Linden, R. A. (1996). Land use planning for conservation and utilization of elderly human resources in Lubbock, Texas: A strategy for sustainable community development. Texas: Texas Tech University.

Loewus, S. E. (2008). Downtown living: for families? The Vancouver, BC urban livability experience and lessons for other cities (Doctoral dissertation, Massachusetts Institute of Technology).

Loukaitou-Sideris, A., Liggett, R. S., Iseki, H., \& Thurlow, W. (2000). Measuring the effects of built environment on bus stop crime.

Lund, H. (2002). Pedestrian environments and sense of community. Journal of Planning education and Research, 21(3), 301-312. http://dx.doi.org/10.1177/0739456X0202100307

Lynch, K. (1981). Good city form. The MIT Press.

Manaf, Z. A., \& Ismail, A. (2010). Malaysian cultural heritage at risk? A case study of digitisation projects. Library Review, 59(2), 107-116. http://dx.doi.org/10.1108/00242531011023862

Mazumder, M. N. H., Ahmed, E. M., \& Al-Amin, A. Q. (2009). Does tourism contribute significantly to the Malaysian economy? Multiplier analysis using IO technique. International Journal of Business and Management, 4(7), P146.

McCann, E. J. (2003). Framing space and time in the city: urban policy and the politics of spatial and temporal scale. Journal of Urban Affairs, 25(2), 159-178. http://dx.doi.org/10.1111/1467-9906.t01-1-00004

McCann, E. J. (2007). Inequality and Politics in the Creative City-Region: Questions of Livability and State Strategy. International Journal of Urban and Regional Research, 31(1), 188-196. http://dx.doi.org/10.1111/j.1468-2427.2007.00713.x

McDonald, N. C. (2008). The effect of objectively measured crime on walking in minority adults. American Journal of Health Promotion, 22(6), 433-436. http://dx.doi.org/10.4278/ajhp.22.6.433

McMillan, T. E. (2007). The relative influence of urban form on a child's travel mode to school. Transportation Research Part A: Policy and Practice, 41(1), 69-79. http://dx.doi.org/10.1016/j.tra.2006.05.011

Ministry of Tourism Malaysia. (2013). Tourist arrivals \& receipts to Malaysia. Retrieved October 1, 2013, from http://corporate.tourism.gov.my/research.asp?page=facts_figures 
Moussaïd, M., Perozo, N., Garnier, S., Helbing, D., \& Theraulaz, G. (2010). The walking behaviour of pedestrian social groups and its impact on crowd dynamics. PloS one, 5(4), e10047. http://dx.doi.org/10.1371/journal.pone.0010047

Muller, T. E. (1996). How personal values govern the post-visit attitudes of international tourists. Journal of Hospitality \& Leisure Marketing, 3(2), 3-24. http://dx.doi.org/10.1300/J150v03n02_02

Nasar, J. L., \& Fisher, B. (1993). 'Hot spots' of fear and crime: a multi-method investigation. Journal of environmental psychology, 13(3), 187-206. http://dx.doi.org/10.1016/S0272-4944(05)80173-2

National Research Council (US). Committee on Identifying Data Needs for Place-Based Decision Making, \& National Research Council (US). Committee on Geography. (2002). Community and Quality of Life: data needs for informed decision making. National Academy Press.

Newman, O. (1972). Defensible space (p. 264). New York: Macmillan.

Nuryanti, W. (1996). Heritage and postmodern tourism. Annals of Tourism Research, 23(2), $249-260$. http://dx.doi.org/10.1016/0160-7383(95)00062-3

Pacione, M. (2003). Urban environmental quality and human wellbeing - a social geographical perspective. Landscape and Urban Planning, 65(1), 19-30. http://dx.doi.org/10.1016/S0169-2046(02)00234-7

Palmer, C. (2005). An ethnography of Englishness: Experiencing identity through tourism. Annals of tourism research, 32(1), 7-27. http://dx.doi.org/10.1016/j.annals.2004.04.006

Partnership for Sustainable Communities. (2011). Livability initiative. Retrieved October 8, 2013, from http://www.fhwa.dot.gov/livability/partnerships/partnerships1.cfm

Partridge, M. D., Rickman, D. S., Ali, K., \& Olfert, M. R. (2009). Do New Economic Geography agglomeration shadows underlie current population dynamics across the urban hierarchy? Papers in Regional Science, 88(2), 445-466. http://dx.doi.org/10.1111/j.1435-5957.2008.00211.x

Rydin, Y., \& Pennington, M. (2000). Public participation and local environmental planning: the collective action problem and the potential of social capital. Local environment, 5(2), 153-169. http://dx.doi.org/10.1080/13549830050009328

Saitluanga, B. L. (2013). Spatial Pattern of Urban Livability in Himalayan Region: A Case of Aizawl City, India. Social Indicators Research, 1-19.

Samimi, A., \& Mohammadian, A. K. (2009). Health impacts of urban development and transportation systems. Journal of Urban Planning and Development, 136(3), 208-213. http://dx.doi.org/10.1061/(ASCE)UP.1943-5444.0000020

Sanford, E. L. (2011). What is the difference between livability and sustainability? Retrieved September 28, 2013, from http://www.camsys.com/kb_experts_livability.htm

Schomberg, Y., Polakit, K., \& Prosperi, D. (2011). Spatial Partitioning of Livability Indices: South Florida Case Study.

Skogan, W. (1986). Fear of crime and neighborhood change. Crime and Justice, $203-229$. http://dx.doi.org/10.1086/449123

Smith, D. M. (1973). The geography of social well-being in the United States: An introduction to territorial social indicators (pp. 85-90). New York: McGraw-Hill.

Solow, R. M. (1991). Sustainability: an economist's perspective.

Steiner, R. (2007). Transportation concurrency: An idea before its time. Growth management in Florida: planning for paradise, 209-226.

Tweed, C., \& Sutherland, M. (2007). Built cultural heritage and sustainable urban development. Landscape and Urban Planning, 83(1), 62-69. http://dx.doi.org/10.1016/j.landurbplan.2007.05.008

UNESCO Bangkok. (2009). Hoi An Protocols for Best Conservation Practice in Asia.

UNESCO. (2008). Melaka and George Town, Historic Cities of the Straits of Malacca. Retrieved October 2 , 2013, from http://whc.unesco.org/en/list/1223

UN-Habitat. (2007). Inclusive and Sustainable Urban Planning: A Guide for municipalities. (Vol. 1). Nairobi: Un-Habitat 
Wateco. (2002). Economics and the Environment - the Implementation Challenge of the Water Framework Directive. Common Implementation Strategy for the Water Framework Directive, Guidance Document No. 1, produced by Working Group 2.6. Luxembourg.

Wilhelmi, O. V., \& Hayden, M. H. (2010). Connecting people and place: a new framework for reducing urban vulnerability to extreme heat. Environmental Research Letters, 5(1), 014021. http://dx.doi.org/10.1088/1748-9326/5/1/014021

Wyatt, R. (2009). Heuristic approaches to urban livability. Malaysian Journal of Environmental Management, $10(1), 43-65$.

Young, E., \& Hermanson, V. (2013). Livability Literature Review: Synthesis of Current Practice. In Transportation Research Board 92nd Annual Meeting (No. 13-2940).

Yung, E. H., \& Chan, E. H. (2011). Problem issues of public participation in built-heritage conservation: Two controversial cases in Hong Kong. Habitat International, 35(3), 457-466. http://dx.doi.org/10.1016/j.habitatint.2010.12.004

Zhu, X., \& Lee, C. (2009). Correlates of walking to school and implications for public policies: survey results from parents of elementary school children in Austin, Texas. Journal of Public Health Policy, S177-S202. http://dx.doi.org/10.1057/jphp.2008.51

Zook, J. B., Lu, Y., Glanz, K., \& Zimring, C. (2012). Design and Pedestrianism in a Smart Growth Development. Environment and Behavior, 44(2), 216-234. http://dx.doi.org/10.1177/0013916511402060

\section{Copyrights}

Copyright for this article is retained by the author(s), with first publication rights granted to the journal.

This is an open-access article distributed under the terms and conditions of the Creative Commons Attribution license (http://creativecommons.org/licenses/by/3.0/). 